\title{
O corpo do manifestante das Jornadas de Junho de 2013: a charge e o editorial da Folha de São Paulo
}

\author{
Marcos Rogério Martins Costa
}

Resumo: Em junho de 2013, as ruas foram tomadas por multidões que queriam grandes reformas econômicas, políticas e sociais. O acontecimento foi nomeado como Jornadas de Junho. Nosso objetivo, neste trabalho, é compreender como o manifestante foi construído na e pela mídia impressa. A partir da semiótica discursiva e da filosofia bakhtiniana, nosso objeto de estudo é o corpo discursivo do ator manifestante. Como metodologia, recuperamos o processo de discursivização do ator manifestante em dois gêneros distintos: a charge e o editorial, ambos publicados no jornal Folha de São Paulo, em 13 de junho de 2015. Como resultado, constatamos que os dois gêneros utilizam-se de diferentes estratégias discursivas para sustentar seu posicionamento axiológico sobre o ator manifestante.

Palavras-chave: semiótica; charge; editorial.

Abstract: The protester body of 2013 June Protests: the charge and the editorial by Folha de São Paulo - On June 2013, the streets were taken by multitudes who wanted great economic, political and social reforms. This event was nominated June Protests. Our objective, in this paper, is to understand how the protester was constructed on and by print media. From the discursive semiotics and Bakhtin's philosophy, our object of study is the discursive protester actors' body. As methodology, we recover the protester actor's discursivization process in two distinct genres: the charge and the editorial, both published by the newspaper Folha de São Paulo, on June 13th, 2015. As a result, we found that in the two genres different discursive strategies are used to sustain their axiological position about the protester actor.

Keywords: semiotics; charge; editorial. 


\section{Introdução}

Em junho de 2013, as ruas foram tomadas por multidões que gritavam, esbravejavam e queriam grandes reformas econômicas, políticas e sociais. $\mathrm{O}$ acontecimento foi nomeado de Jornadas de Junho. Essas manifestações populares começaram em São Paulo-SP motivadas, a princípio, pelo aumento da tarifa do transporte público que entrara em vigor no dia 2 de junho. Depois do quarto ato de protesto contra o aumento, as mobilizações alastraram-se pelo País. Como afirmam Nobre (2013a) e Seco (2013), os protestos que integraram a Jornadas de Junho podem ser considerados como a maior mobilização popular do período de redemocratização brasileiro. Diante desse panorama, nosso interesse nesse marco histórico recente é compreender como o manifestante de rua foi construído na e pela mídia impressa.

Para tanto, tomamos como objeto de estudo o corpo discursivo do ator manifestante. Entendemos o corpo discursivo como uma unidade de sentido que respalda um sujeitono-mundo, como propõe Discini (2015, p. 17):

Um corpo que se encerra numa consciência que transcende de si para o outro, seja este outro o mundo no qual o sujeito se instala ao tomar posição, ao julgar e fazer julgar, seja este outro o mundo no qual o sujeito se instala enquanto é afetado pelo que lhe sobrevém e o atinge sensivelmente, é precário e inacabado.

Essa concepção semiótica de corpo entende a enunciação como instância pressuposta ao enunciado. Desse modo, o que nos interessa é o referente interno, isto é, o referente imanente à linguagem. O sujeito-no-mundo é caracterizado por um contrato fiduciário afiançado entre os parceiros da comunicação (enunciador-enunciatário). É esse contrato fiduciário que determina o estatuto veridictório do discurso.

Para investigarmos o corpo discursivo que afeta e é afetado pelo mundo que o constitui dialogicamente nas diferentes estratégias discursivas adotadas pelo sujeito da enunciação, recuperamos o processo de discursivização do ator do enunciado manifestante em dois gêneros distintos: a charge e o editorial. Entendemos gênero, na concepção bakhtiniana, como um enunciado relativamente estável que circula em determinada esfera de atividade humana (BAKHTIN, 2006).

Para tanto, selecionamos como corpus a charge do cartunista Benett Alberto de Macedo, conhecido como Benett (MACEDO, 2013), e o editorial "Retomar a Paulista" (FOLHA DE SÃO PAULO, 2013), ambos publicados na página A2 da Folha de São Paulo do dia 13 de junho de 2013. O critério de seleção do jornal e dos textos nele veiculados se deve à relevância e à abrangência da cobertura jornalística desse canal, que é um dos veículos de comunicação de maior circulação no Brasil e um dos mais antigos. ${ }^{1}$

1 A primeira publicação da Folha de São Paulo foi em 19 de fevereiro de 1921, ainda com a alcunha de Folha da Noite. A sua média de venda diária, incluindo as edições impressa e digital, totaliza 342,2 mil no País. O Estado de São Paulo contribui com a maior parte dessa venda, consumindo cerca de 250,7 mil exemplares diários, conforme dados divulgados em 29 de junho de 2014 pelo Instituto Verificador de Circulação (IVC). 
Além disso, a edição do dia 13 de junho é anterior ao confronto entre policiais e imprensa ocorrido durante o quarto ato de protesto. Esse fato modificou o posicionamento discursivo da grande imprensa, conforme sustentam Moreira e Santiago (2013, p. 17): "A mídia, após, inicialmente, chamar os manifestantes de vândalos e baderneiros, resolveu fazer uma virada espetacular de opinião e passou a apoiá-los". Eis o que justifica o nosso interesse em estudar o posicionamento midiático anterior a essa reviravolta axiológica de um dos veículos da grande imprensa.

A abordagem teórico-metodológica da semiótica será mister para investigarmos os processos de significação dos textos selecionados. Com base nesse arcabouço teórico, exploraremos as características das estratégias discursivas do corpus selecionado utilizadas para construir o corpo discursivo do manifestante, cotejando, para isso, os elementos que caracterizam um gênero discursivo, a saber: a temática, a composição e o estilo (BAKHTIN, 2006). ${ }^{2}$

Conforme Bakhtin (2006) explica, a temática não é o assunto tratado pelo texto, mas é o recorte de sentido que o próprio gênero faz em intersecção com o posicionamento do autor-criador - em termos semióticos, com o sujeito da enunciação. Podemos recuperar semioticamente a temática pelo estudo da semântica discursiva do texto. A composição, por sua vez, corresponde à organização do texto. Em termos semióticos, podemos apreendê-la por meio da organização das categorias discursivas de pessoa, tempo e espaço, bem como dos processos de textualização realizados. O estilo diz respeito à entonação própria de cada texto. Pelo viés semiótico, podemos entender essa entonação pela totalidade das marcas linguísticas e discursivas reunidas no e pelo gênero.

Conforme propõe Discini (2003), é possível ainda distinguir estilo de gênero e estilo autoral: este está menos submetido às coerções do gênero. Por exemplo, a literatura é mais propícia ao fortalecimento do estilo autoral do que uma receita médica. Isso evidencia que o estilo de gênero está presente em todo enunciado, às vezes mais fortalecido, às vezes menos, o que, neste último caso, enrobustece o estilo autoral. Baseados nesses pressupostos, analisaremos, a seguir, os dois gêneros selecionados e suas respectivas estratégias discursivas.

\section{A charge e suas estratégias discursivas}

De forma geral, a charge jornalística traz em sua tessitura discursiva elementos da sátira, pois, como explica Moisés (2013, p. 424), "a sátira continua a ser praticada, ainda que de maneira difusa e ocasional". Em específico, Kurtz (2009) explica que "a charge é classificada como formato opinativo, ou seja, uma forma de expressão que ostenta um inegável potencial persuasivo [...]" (KURTZ, 2009, p. 65). Temos, assim, um gênero opinativo que retrata satiricamente um acontecimento recente. Sua esfera de circulação é, por sua vez, diversa: jornais, revistas, blogs, dentre outras.

2 O conceito de estratégia discursiva designa, no âmbito da semiótica da Escola de Paris, as operações do sujeito da enunciação para "a colocação em discurso (ou discursivização) das estruturas narrativas" (GREIMAS; COURTÉS, 2008, p. 182). 
A charge que selecionamos para este estudo vem recortar tematicamente a pauta dos primeiros dias de junho de 2013: os prejuízos do vandalismo ocorrido durante as manifestações contra o aumento da tarifa de transporte público organizado pelo Movimento Passe Livre (MPL). ${ }^{3}$ Tendo em vista o estilo sério-cômico típico da charge que desestabiliza o statu quo, a charge de Benett, publicada no dia 13 de junho, possui uma meta persuasiva dupla. Primeiramente, ela vem provocar o humor, o riso, a sátira; daí a charge ser considerada cômica. Em segundo lugar, ela implicitamente objetiva construir o seu contrato veridictório com o enunciatário-leitor, de tal modo que este concorde com a sua crítica - nesse caso, os atos de vandalismo ocorridos durante as manifestações de rua. Eis aí o caráter sério da charge.

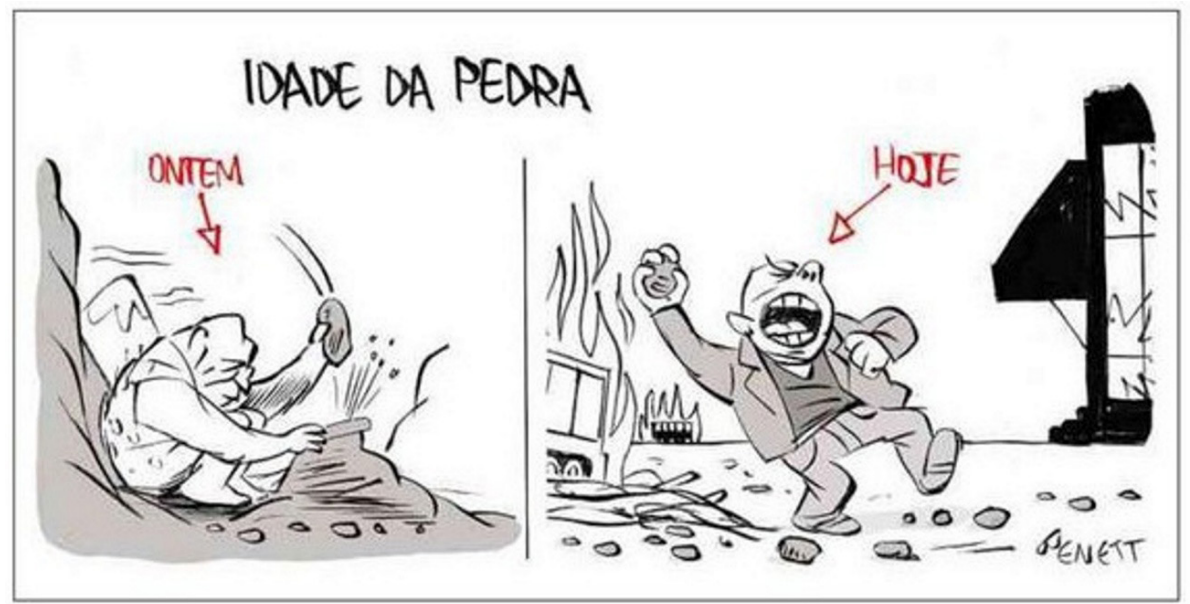

Fig.1. Charge de Benett, publicada na Folha de São Paulo de 13 de junho de 2013.

Fonte: Acervo da Folha de São Paulo. Disponível em: < http://acervo.folha.com.br/ >. Acessado em: 28 jan. 2016.

Na charge de Benett, o estilo sério-cômico satiriza a ação de vandalismo ocorrida durante a manifestação de rua ao emparelhar, de um lado, o hominídeo do Período Paleolítico, a primeira fase da Idade da Pedra (cerca de 2,5 milhões de anos a.C. até 10 mil anos a.C.) e, de outro, o homem que depreda ônibus e prédios. O primeiro, ancorado verbalmente na figura do ontem, e o segundo, na do hoje, escritos em vermelho. Sendo assim, as fronteiras do passado e do presente se borram e, com isso, uma figura retórica se manifesta: a metáfora. No caso, temos a metáfora de que o vândalo pode ser considerado um homem das cavernas.

3 MPL é uma organização descentralizada de luta que reivindica o passe livre e gratuito para todos e um transporte público de qualidade. Sua primeira mobilização aconteceu em Salvador-BA, nomeada Revolta do Buzu, entre os meses de agosto e setembro de 2003. Depois, ganhou força e organização na Revolta da catraca, em Florianópolis-SC, no ano de 2004. O movimento continuou crescendo até ganhar dimensão nacional nas Jornadas de Junho de 2013. 
Com isso, o corpo do manifestante das Jornadas de Junho vai pouco a pouco ganhando, na semântica do discurso desse gênero, determinadas características. Essas vão, ao mesmo tempo, afiançando o posicionamento do sujeito da enunciação, bem como construindo uma axiologia sobre o sujeito do enunciado. Para tanto, a metáfora que faz a associação vândalo/hominídeo da Idade da Pedra traz um contributo temático-figurativo de grande densidade discursiva para a corporeidade do manifestante. Como explica Fiorin (2014), a metáfora é uma figura retórica que corrobora propriedades semânticas concentradas e tônicas:

A metáfora é uma concentração semântica. No eixo da extensão, ela despreza uma série de traços e leva em conta apenas alguns traços comuns a dois significados que coexistem. Com isso, dá concretude a uma ideia abstrata [...], aumentando a intensidade do sentido. Poder-se-ia dizer que o sentido torna-se mais tônico. Ao dar ao sentido tonicidade, a metáfora tem um valor argumentativo muito forte (FIORIN, 2014, p. 34).

Compreendemos, assim, que o estilo do gênero sério-cômico da charge, ao utilizar o recurso da metáfora em sua forma composicional, amplia a densidade discursiva de sua temática, que é a de sátira e crítica aos atos de vandalismo durante a mobilização popular nas vias públicas da cidade de São Paulo-SP - especificamente no objeto em análise. Esse estilo sério-cômico da charge faz com que ela se destaque dentre os textos opinativos veiculados no jornal, como explica Romualdo (2000, p. 15):

\begin{abstract}
Se pensarmos em termos de conteúdo, uma charge ou uma caricatura podem ser muito mais densas do que os outros textos opinativos, como uma crônica ou até mesmo um editorial. O leitor pode, inclusive, deixar de ler estes e outros gêneros opinativos convencionais, optando pela leitura da charge que, por ser um texto imagético e humorístico, atrai mais sua atenção e lhe transmite mais rapidamente um posicionamento crítico sobre personagens e fatos políticos.
\end{abstract}

Além do estilo sério-cômico, temos, como observou Romualdo (2000), outro elemento característico da charge: a sua composição sincrética. Sendo um texto sincrético, a charge associa, na maioria dos casos, uma linguagem verbal a uma linguagem visual, como vemos na charge de Benett (Figura 1). Nesses casos, uma linguagem convoca a outra, isto é, a parte verbal complementa a parte visual; e vice-versa.

Ressalta-se que a ancoragem temporal ontem/hoje e o título Idade da Pedra-embora este esteja mais próximo do marco referencial ontem do que do de hoje na disposição topológica da charge - parecem estar em movimento, como se a Idade da Pedra fosse em direção ao hoje. Essa disposição, portanto, corrobora a diluição das fronteiras temporais, e configura um acontecimento concessivo no texto. 
Seguindo esse raciocínio, há uma lógica da concessão que fomenta a sátira e o riso na charge, tanto quanto a crítica ao vandalismo sustentada pelo posicionamento axiológico do sujeito da enunciação. Essa concessão é paradoxal porque rompe as expectativas. E é isso o que ocorre na charge. No período da Pré-História, nomeado culturalmente de Idade da Pedra e figurativizado no texto como ontem, o homem utilizava a pedra lascada para a fabricação de ferramentas, machados, lanças e outros instrumentos úteis à vida em sociedade, ou mesmo dentro de seus pequenos grupos nômades. Assim, esperava-se que, na sociedade de hoje, pós-revolução industrial, tecnológica e digital, o homem utilizasse a pedra para outros fins que não o de destruir patrimônios públicos, como os ônibus, ou bens privados, como as fachadas de bancos. Essa expectativa é rompida.

$\mathrm{Na}$ ancoragem temporal do hoje, construída na charge, observamos um homem de terno, com expressão furibunda, preparando-se para atirar uma pedra. Ao fundo, aparecem ônibus em chamas e pelo menos um prédio com as vidraças quebradas. Em termos da semiótica tensiva, temos, portanto, a lógica concessiva (em uma fórmula didática: embora $X, Y$ ) preponderando sobre a lógica implicativa (se $X, \operatorname{logo} Y$ ).

Conforme explica Zilberberg (2011), a lógica da concessão predomina quando temos a passagem do não possível ao possível, ou seja, do irrealizável, do ponto de vista do esperado, para o realizável, na ótica do inesperado. Logo, a concessão é um contraprograma que desestabiliza o mundo do possível, o que instaura, de forma abrupta, o mundo do inesperado, do surpreendente, enfim, do acontecimento (cf. ZILBERBERG, 2011).

Novamente, confirma-se a maior tonicidade e concentração semântica na charge, visto que há um grande impacto na quebra de expectativa quando o homem de hoje age diferentemente do esperado, isto é, ao invés de construir, ele destrói. Ou melhor, há uma grande surpresa quando o homem de ontem executa atividades mais benevolentes para a sociedade do que o homem de hoje, pois, na charge, enquanto o hominídeo fabrica utensílios, o homo sapiens sapiens depreda bens públicos e privados.

Além disso, podemos observar que a charge, em sua composição sincrética, associando a linguagem verbal à visual, conseguiu evidenciar que a descrição da categoria do tempo na língua(gem) nada tem a ver com o tempo físico e o tempo cronológico (BENVENISTE, 2005; 2006). Benveniste (2005) explica que o tempo linguístico é diferente do tempo físico e do cronológico. O tempo físico é uma duração, portanto, ele é medido pelo movimento de algum referencial na relação entre o momento anterior e o momento posterior, por exemplo, quando elegemos os astros como referentes e marcamos a duração em horas, dias, meses, anos etc.

Já o tempo cronológico é o tempo dos acontecimentos; para isso, é preciso fixar um momento no tempo físico, que servirá como referencial, e então passar a contar o tempo dos fatos decorrentes depois desse ponto fixo. Um exemplo de tempo cronológico é o calendário mais popular em uso no mundo atual, conhecido como Calendário Gregoriano ou Calendário Ocidental, estabelecido em 1582. 
A diferença do tempo linguístico é que ele se constitui no ato de tomar a palavra, isto é, na e pela enunciação enunciada. Logo, o momento em que o eu enuncia é o agora e, a partir desse marco referencial, constitui-se o tempo linguístico. Essa peculiaridade do tempo linguístico acarreta dinamicidade na produção e interpretação do sentido, sustentando, assim, o seu caráter intersubjetivo.

No caso da charge, o enunciador poderia escolher entre diversas formas de construir seu posicionamento frente aos atos de vandalismo praticados durante as manifestações de rua. Diante dessas possibilidades, o sujeito da enunciação, ao estabelecer seu contrato fiduciário (fazer-crer) e manipulatório (fazer-fazer), instaurou um agora que borra os contornos entre o passado e o presente. Isso ocorre porque, embora o gênero recupere tematicamente um fato ligado ao escopo pragmático recente (o vandalismo ocorrido durante o terceiro ato de protesto contra o aumento da tarifa), o sujeito da enunciação efetuou uma metáfora, avizinhando o hominídeo da Idade da Pedra e o vândalo das manifestações.

Essa metáfora, como demonstramos a partir de Fiorin (2014), efetivou uma concentração semântica que, ao levar em consideração apenas alguns traços e desprezar uma série de outros - como, por exemplo, a distância enorme tanto no tempo cronológico quanto no tempo físico entre o homem de ontem e o homem de hoje -, aumentou a intensidade do sentido no riso e também na crítica.

Diante dessas estratégias discursivas, podemos afirmar que o componente sensível robusteceu o componente ideológico do sujeito da enunciação no gênero charge, visto que o riso do enunciatário afiança os valores disfóricos associados ao corpo discursivo do manifestante, ator do enunciado, figurativizado e tematizado como vândalo e homem primitivo. Nesse gênero, por meio do sensível, o enunciatário é levado a entrar em conjunção com os objetos-de-valor do enunciador, conforme demonstram as categorias tensivas propostas por Zilberberg (2011).

\section{O editorial e suas estratégias discursivas}

As estratégias discursivas utilizadas pelo sujeito da enunciação do gênero editorial são bem diferentes. A configuração discursiva do editorial é bem diferente da do gênero charge. Na forma composicional, o gênero editorial é predominantemente temático e somente verbal, enquanto, como vimos, a charge é temático-figurativa e verbo-visual. No que se refere à temática, o editorial, ao tratar de análises e intepretações dos fatos veiculados nas primeiras páginas, discute dados do contexto pragmático imediato, retomando, assim, de maneira interdiscursiva, tais páginas. Ressaltamos que o editorial pode se nutrir das manchetes e de notícias dos dias anteriores também. Por isso, na temática do gênero editorial, o escopo do contexto pragmático é maior do que na temática da charge. Em outros termos, os interdiscursos aparecem mais no contrato fiduciário do texto do editorial do que no da charge. ${ }^{4}$

4 Utilizamos o termo contexto pragmático a partir da concepção bakhtiniana em uma visada discursiva, conforme propõe Discini (2015). Por isso, consideramos que esse conceito remete aos (inter)discursos presentes e resgatados pelo estilo do gênero e pelo estilo autoral no processo de construção do texto. 
Além disso, por se tratar, na maioria das vezes, de um texto sem assinatura individual, o editorial respalda o ponto de vista assumido pelo próprio veículo que o faz circular nas esferas de atuação humana - o jornal. Logo, a entonação do editorial remete a um enunciador coletivo. Enquanto a charge possui um estilo autoral mais fortemente marcado, o estilo autoral do editorial é mais retraído, visto que ele veicula a opinião de um enunciador coletivo, ou seja, o jornal Folha de São Paulo. Prepondera, na charge, o estilo autoral; no editorial, o estilo de gênero.

Selecionamos, para discutir o gênero editorial, o texto "Retomar a Paulista", o qual reproduzimos integralmente em anexo. Devido à dimensão espaço-temporal deste estudo, não vamos recuperar todas as estratégias discursivas articuladas para sustentar o posicionamento do sujeito da enunciação nesse editorial. Focalizaremos os elementos textuais que, ao fortalecerem a temática, a forma composicional e estilo do gênero editorial, afiançam o posicionamento discursivo do sujeito da enunciação. Para tanto, manteremos nosso interesse na construção do ator do enunciado manifestante.

O título "Retomar a Paulista" já traz uma pequena narrativa: algo foi tomado, é preciso re-tomar. No caso, o objeto a ser recuperado é a Avenida Paulista. Além disso, o título pode ser interpretado como um pedido, um conselho ou uma ordem. Nas três possibilidades, temos a imagem de um enunciador bastante competente: no primeiro caso, um sujeito que tem credibilidade para pedir (crer); no segundo, tem o conhecimento necessário para aconselhar (saber); e no terceiro, pode mandar (poder). A imagem do enunciatário, por sua vez, é construída como aquele que, seguindo as três interpretações possíveis, pode aderir ou não ao pedido, aceitar ou não o conselho, ou ainda, acatar ou não a ordem. Vamos observar nos parágrafos seguintes do editorial como o enunciador manipula o enunciatário a entrar em conjunção com o seu pedido/conselho/ordem.

Logo, a seguir do título, temos acesso à asserção do posicionamento discursivo do enunciador e de dois de seus principais argumentos: “Avenida vital de São Paulo se tornou território preferido de protestos abusivos, que prejudicam milhões para chamar a atenção do público" (FOLHA DE SÃO PAULO, p. A2, 13/06/2013). O posicionamento discursivo do enunciador que recorta o assunto na temática do gênero é contrário às manifestações, como podemos verificar pelo uso do adjetivo negativo "abusivos" para qualificar os protestos. Os dois argumentos que sustentam essa reprovação são: (i) os protestos "prejudicam milhões [de paulistanos]" e (ii) os protestos são de um grupo minoritário que deseja "chamar a atenção do público". O primeiro argumento reforça o segundo, pois, se os protestos prejudicam milhões de pessoas, é porque milhões de pessoas não participam dos protestos - pode-se pressupor, assim, que o grupo organizador é minoritário.

Nos parágrafos seguintes, esses argumentos são reforçados. Para isso, na forma composicional, o enunciador utiliza diversos recursos. Ao se contrapor aos protestos, temos configurada uma cenografia de polêmica: de um lado, o jornal Folha de São Paulo, defendendo o argumento de que "o direito de manifestação é sagrado, mas não está 
acima da liberdade de ir e vir" (FOLHA DE SÃO PAULO, p. A2, 13/06/2013), e de outro, o "grupelho" que, "cientes de sua condição marginal e sectária, os militantes lançam mão de expediente consagrado pelo oportunismo corporativista: marcar protestos em horário de pico de trânsito na Avenida Paulista, artéria vital da cidade" (FOLHA DE SÃO PAULO, p. A2, 13/06/2013). Tanto o uso de "grupelho", que determina geralmente um grupo pequeno, uma facção insignificante, quanto a predicação da estratégia utilizada ("oportunismo corporativista"), definem um modo de dizer recorrente que vai valorizando negativamente o corpo do manifestante.

Diversos elementos predicativos de caráter pejorativo são elencados a fim de afiançar essa disforia para com o corpo discursivo do manifestante. Citamos, como exemplos, algumas das passagens que descrevem os manifestantes do MLP: "jovens predispostos à violência por uma ideologia pseudorrevolucionária, que buscam tirar proveito da compreensível irritação geral com o preço pago para viajar em ônibus e trens superlotados"; "Os poucos manifestantes que parecem ter algo na cabeça além de capuzes" (FOLHA DE SÃO PAULO, p. A2, 13/06/2013). Esses elementos figurativos, quando juntos, constroem o tema de aversão aos protestos dos manifestantes. Sustenta-se, assim, a axiologização de que essa atuação dos manifestantes é danosa e infringe o próprio direito democrático, uma vez que os manifestantes demonstram, com os atos de protesto, interditando a Avenida Paulista, "a ignorância de um preceito básico do convívio democrático: cabe ao poder público impor regras e limites ao exercício de direitos por grupos e pessoas quando há conflito entre prerrogativas" (FOLHA DE SÃO PAULO, p. A2, 13/06/2013). Esse é o modo como o enunciador-jornal instaura e valida a sua axiologização na semântica discursiva do texto.

Para fazer o enunciatário-destinatário aderir a esse posicionamento, o enunciadordestinador manipulador constrói um efeito de aproximação que utiliza a temporalização discursiva em uma desinência modo-temporal do presente do indicativo. Desse modo, no editorial, a instância enunciativa se discursiviza por meio da referencialização temporal cravada num agora, como podemos observar no seguinte trecho: "É hora de pôr um ponto final nisso. Prefeitura e Polícia Militar precisam fazer valer as restrições já existentes para protestos na Avenida Paulista, em cujas imediações estão sete grandes hospitais" (FOLHA DE SÃO PAULO, p. A2, 13/06/2013, grifos nossos).

Nesse excerto temos, no nível narrativo, a meta persuasiva do destinador-manipulador implícita: "pôr um final nisso"; e o fazer-fazer do destinatário-sujeito esclarecido: "fazer valer as restrições já existentes para protestos". Essa manipulação é discursivizada no modotemporal do presente do indicativo porque o enunciador-destinador-manipulador quer fazer o enunciatário-destinatário-sujeito entrar em conjunção com o seu posicionamento discursivo no agora da enunciação enunciada. Para isso, ele constrói no enunciado uma debreagem temporal enunciativa que simula o agora da enunciação, corroborando, assim, para o efeito de aproximação entre enunciador e enunciatário.

Esse modo de construir o discurso no editorial evidencia mais uma vez que o tempo linguístico é distinto do tempo físico e cronológico, como já observamos na análise 
do gênero anterior. Mas no editorial "Retomar a Paulista", diferentemente do que ocorreu na charge, a temporalidade linguística simula o agora da enunciação, que retoma mais elementos do escopo do contexto pragmático imediato. Recuperamos, assim, alguns dos elementos principais da forma composicional deste corpus.

O modo de enunciar do editorial produz a entonação e a imagem de quem sabe o que fala (DISCINI, 2004). Por isso, em "Retomar a Paulista", o enunciador emprega juízos assertivos. O tom do editorial, por sua vez, é imponente, utilizando a variante padrão da língua na norma culta para produzir tal efeito. Por exemplo, no último parágrafo do editorial: "No que toca ao vandalismo, só há um meio de combatê-lo: a força da lei. Cumpre investigar, identificar e processar os responsáveis. Como em toda forma de criminalidade, aqui também a impunidade é o maior incentivo à reincidência" (FOLHA DE SÃO PAULO, p. A2, 13/06/2013).

Nesse trecho, temos três frases com diferentes recursos estilísticos. Recuperemos alguns deles. Na primeira, há uma inversão da ordem dos termos da subordinação: a oração subordinada é topicalizada, antecedendo a oração principal. Além disso, temos o recurso de apresentação do segmento "a força da lei" destacado do período, utilizando, para isso, a pontuação (dois pontos, ponto final) e o deslocamento da posição desse segmento para o final do período. Na segunda, há a figura retórica da gradação, propondo "uma sequência de significados dispostos numa ordem ascendente, em que o posterior diz um pouco mais do anterior" (FIORIN, 2014, p. 147). Esse recurso estilístico provoca um efeito de sentido de intensificação crescente. Na terceira, temos novamente a inversão de termos da oração, mas, para além disso, o uso reiterado de substantivos abstratos (criminalidade, impunidade, reincidência), que produz um efeito de sentido de generalidade do dizer.

Todas essas estratégias depreendidas nos permitem recuperar a imagem do enunciador, com corpo, voz e caráter próprios, como explica Discini (2004), ao estudar o gênero editorial na grande imprensa:

Tais estratégias supõem hábito de leitura determinado por idas e vindas, como pré-requisito para a construção do simulacro da voz séria e refinadamente intelectualizada, do corpo altivo, do caráter de "quem sabe das coisas", traços construídos para o sujeito pressuposto a esse tipo de imprensa e a esse gênero que a constitui, o editorial. (DISCINI, 2004, p. 137).

Os recursos de discursivização e textualização efetuados no editorial "Retomar a Paulista", juntos, contribuem para a construção de determinada valoração e axiologização do mundo e de seus fenômenos: rejeição aos protestos que interditaram a Avenida Paulista. Para alcançar adesão ao seu posicionamento, no editorial, produz-se um contrato veridictório que afiança certos valores disfóricos para o corpo discursivo do ator do enunciado manifestante, enquanto se traça nas linhas e nas entrelinhas a imagem de enunciador-jornal, que sabe do que fala, e a imagem de seu enunciatário-leitor, que quer-saber do que se fala. 
Para tanto, no editorial, pautam-se suas estratégias discursivas mais pela lógica da implicação (se X, logo Y) do que pela lógica da concessão (embora X, Y), uma vez que o sujeito da enunciação está convicto de que "o mundo é justamente o 'seu' mundo, onde têm lugar o cálculo e a previsão [...]" (ZILBERBERG, 2011, p. 243). Portanto, nesse gênero, por meio do inteligível, o enunciatário é levado a entrar em conjunção com os objetos-de-valor do enunciador. Temos, assim, uma maior inteligibilidade, porque a lógica da implicação prepondera sobre a da concessão.

\title{
Considerações finais
}

A partir dos três elementos constitutivos de um gênero, a temática, a forma composicional e o estilo, fomos depreendendo, ao longo deste estudo, como o sujeito da enunciação arquitetava o ator do enunciado para avaliar e validar seu posicionamento. Tanto a charge quanto o editorial sustentaram um posicionamento contrário às manifestações. Para esse fim, elas construíram o corpo do ator manifestante com determinada sintaxe e semântica discursivas. Em termos gerais, o manifestante, na charge, foi associado ao tema do vandalismo; no editorial, ele foi figurativizado diversas vezes de forma negativa.

Levando em consideração a proposta de Discini (2015), podemos dizer que a corporeidade do ator do enunciado é parte fundamental da fala conotada do ator da enunciação:

\begin{abstract}
Todos esses gestos, relativos a uma fala conotada, fazem o ator tomar corpo a partir de um sistema de remissão do dado ao não dado, o que permite ao próprio corpo fundar-se num esquema de avaliações, respaldado por formações discursivas, e num algoritmo da percepção, suscetível de ser registrado na cifra tensiva, a qual remete ao modo como é processada a percepção em cada enunciado e na totalidade (DISCINI, 2015, p. 376).
\end{abstract}

Por conseguinte, o corpo do ator da enunciação manifestante remete a todo o sistema de crenças e valores que o ator da enunciação Folha de São Paulo sustenta para afiançar seu contrato veridictório (crer-ser) e manipulatório (fazer-fazer) com seu público-leitor. Isso fica evidente pelo tom pejorativo utilizado sobre as Jornadas de Junho, assumido tanto na charge quanto no editorial. Todavia, o modo de fazê-lo é distinto em cada um dos gêneros: na charge, satiriza-se o manifestante comparando-o ao hominídeo da Idade da Pedra; já no editorial, argumenta-se o risco de se perder o direito de ir e vir do cidadão devido à ação de "jovens predispostos à violência por uma ideologia pseudorrevolucionária" (FOLHA DE SÃO PAULO, p. A2, 2013).

Seja pela sátira, com mais enunciados de concessão, seja pela argumentação, com mais enunciados implicativos, o corpo do ator do enunciado, nesse caso, o manifestante, perde força diante do ator da enunciação que, ao construí-lo, encarna-o a seu bel-prazer. Logo, nota-se que o fazer-crer da mídia impressa não se reduz às coerções do gênero, nem 
à assinatura de quem desenha a charge ou ao sujeito coletivo que assina implicitamente o editorial. Ele está impresso na própria mídia. Prova disso é que o sujeito manifestante no corpus analisado é recortado conforme a postura axiológica afiançada pelo jornal Folha de São Paulo em dois gêneros discursivos completamente diferentes.

Marcos Rogério Martins Costa é doutorando do PPG Semiótica e Linguística Geral do Departamento de Linguística da USP e bolsista CNPq. marcosrmcosta15@gmail.com.

\section{Referências}

BAKHTIN, M. M. Gêneros do discurso. In: . Estética da criação verbal. Tradução de Paulo Bezerra. 4. ed. São Paulo: Martins Fontes, 2006, p. 261-306.

BENVENISTE, E. Problemas de linguística geral I. Tradução de Maria da Glória Novak e Maria Luisa Neri. 5. ed. Campinas: Pontes Editores, 2005.

Problemas de linguística geral II. Tradução de Eduardo Guimarães et al. 2. ed. Campinas: Pontes Editores, 2006.

DISCINI, N. O estilo nos textos: histórias em quadrinhos, mídias, literatura. 2. ed. São Paulo: Contexto, 2003.

. A imagem do enunciador na mídia. In: BASTOS, N. B. (Org.). Língua Portuguesa em calidoscópio. São Paulo: Educ; Fapesp, 2004, p. 133-141.

Corpo e estilo. São Paulo: Contexto, 2015.

FIORIN, J. L. Figura de retórica. São Paulo: Contexto, 2014.

FOLHA DE SÃO PAULO. Retomar a Paulista. São Paulo, p. A2, 13/06/2013. Disponível em: < http:// acervo.folha.com.br/ >. Acessado em: 28 jan. 2016.

GREIMAS, A. J.; COURTÉS, J. Dicionário de semiótica. Tradução de Alceu Dias Lima et al. São Paulo: Contexto, 2008.

KURTZ, A. S. Charge jornalística. In: FILHO MARCONDES, C. (Org.). Dicionário da comunicação. 2. ed. São Paulo: Paulus, 2009, p. 65-66.

MACEDO, B. A. de. Charge. Folha de São Paulo. São Paulo, p. A2, 13/06/2013. Disponível em: < http://acervo.folha.com.br/ >. Acessado em: 28 jan. 2016.

MOISÉS, M. Sátira. In: Dicionário de termos literários. 12. ed. São Paulo: Cultrix, 2013, p. 424-425.

MOREIRA, O. de L.; SANTIAGO, I. M. F. L. Vem pra rua: os protestos de junho. In: SOUSA, A. de A.; SOUSA, C. M. de. Jornadas de junho: repercussões e leituras. Campina Grande: EDUEPB, 2013, p. 13-21.

NOBRE, M. Imobilismo em movimento: da abertura democrática ao governo Dilma. São Paulo: Companhia das Letras, 2013.

ROMUALDO, E. C. Charge jornalística: intertextualidade e polifonia: um estudo de charges da Folha de S. Paulo. Maringá: Eduem, 2000. 
SECCO, L. As Jornadas de Junho. In: MARICATO, E. (Org.) Cidades rebeldes: Passe Livre e as manifestações que tomaram as ruas do Brasil. São Paulo: Boitempo; Carta Maior, 2013, p. 71-78.

ZILBERBERG, C. Elementos da gramática tensiva. Trad. de Ivã Lopes, Luiz Tatit e Waldir Beividas. São Paulo: Ateliê Editorial, 2011.

\section{Anexo}

\section{Retomar a Paulista}

\author{
Avenida vital de São Paulo se \\ tornou território preferido \\ de protestos abusivos, que \\ prejudicam milhões para \\ chamar a atenção do público
}

Oito policiais militares e um númerodesconhecido de manifestantes feridos, 87 ônibus danificados, RS 100 mil de prejuízos em estações de metrô e milhões de paulistanos reféns do trânsito. Eis o saldo do terceiro protesto do Movimento Passe Livre (MPL), que se vangloria de parar São Paulo - e chega perto demais de consegui-lo.

Sua reivindicação de reverter o aumento da tarifa de ônibus e metrô de RS 3 para RS 3,20 -abaixo da inflação, é útil assinalar - não passa de pretexto, e dos mais vis. São jovens predispostosà violência por uma ideologia pseudorrevolucionária, que buscam tirar proveito da compreensivel irritação geral com o preço pago para viajar em ônibus e trens superlotados.

Pior que isso, só o declarado objetivo central do grupelho: transporte público de graça. $O$ irrealismo da bandeira já trai a intenção oculta de vandalizar equipamentos públicos e o que se toma por símbolos do poder capitalista. 0 que vidraças de agências bancá. rias têm a ver com ônibus?

Os poucos manifestantes que parecem ter algo na cabeça além de capuzes justificam a violência como reação à suposta brutalida. de da polícia, que acusam de reprimir o direito constitucional de manifestação. Demonstram, com isso, a ignorância de um preceito básico do convívio democrático: cabe ao poder público impor regras e limites ao exercício de direitos por grupos e pessoas quando há conflito entre prerrogativas.

0 direito de manifestação é sagrado, mas não está acima da liberdade de ir e vir - menos ainda quando oprimeiroéreclamadopor poucos milhares de manifestantes e a segunda é negada a milhões.

Cientes de sua condição marginal e sectária, os militantes lançam mão de expediente consagrado pelo oportunismo corporativista: marcar protestos em horário de pico de trânsito na avenida Paulista, artéria vital da cidade. Sua estratégia para atrair a atenção pública é prejudicar o número máximo de pessoas.

É hora de pôr um ponto final nisso. Prefeitura e Polícia Militar precisam fazer valer as restrições já existentes para protestos na avenida Paulista, em cujas imediaçôes estão sete grandes hospitais. Não basta, porém, exigir que organizadores informem à Companhia de Engenharia de Tráfego (CET), 30 dias antes, o local da manifestação. A depender de horário e número previsto de participantes, o poder público deveria vetar as potencialmente mais perturbadoras e indicar locais alternativos.

No que toca ao vandalismo, só há um meio de combatê-lo: a força da lei. Cumpre investigar, identificar e processar os responsáveis. Comoem toda forma de criminalidade, aqui também a impunidade é o maior incentivo à reincidência. 